\title{
THE PRESENT STATUS OF MONETARY AND FISCAL POLICY
}

\author{
PaUl W. McCracken \\ University of Michigan
}

The successive developments in monetary and fiscal policy, as Williams has pointed out, have been toward gaining progressively more initiative in influencing the volume of aggregate spending and national income. 1

Discount policy seemed insufficient because a low discount rate, for example, encouraged but did not guarantee an easier reserve position through rediscounting, and therefore an expansion of bank credit, and therefore an upward response by business activity.

Attention gradually shifted to open market operations. With this activity the monetary authority did not have to await the initiative of the commercial banks in the creation of reserves. Through an affirmative use of open market purchases or sales, the Federal Reserve had acquired the initiative in the creation of reserves. But this did not prove to be the perfect answer. Particularly was this true when the problem was to encourage a recovery from low levels of business activity. Excess reserves could be created, but what if people did not want to borrow?

In the thirties our attention turned to the deliberate use of the governmental-receipts spending process as a way of influencing the level of national income. This was basically a logical extension of the evolution of monetary policy. If the private sector of the economy could not be counted on to borrow and thus activate the business situation, we would rely on governmental deficits to precipitate the borrowing and spending. This constituted one further step, it was hoped, toward tightening the relation between policies pursued and results desired - a rise in the volume of spending and national income. So complete was this shift of emphasis, however, that we no longer considered ourselves operating within the ambit of monetary policy. These new policies incident to the governmental-receipts spending process were fiscal policies.

1 John H. Williams, "Deficit Spending," American Economic Review, Proceedings; reprinted in his Postwar Monetary Plans and Other Essays (New York: Knopf, 1947), chap. 9. 
Unaccustomed to performing in the role of minister without portfolio, monetary policy looked around for something else to do and found it. This was the maintenance of more orderly conditions in the capital markets. Something which we have heard a great deal about in the war and postwar period, its origin is back at least as far as 1937. In that year, and again in 1939, the Federal Reserve stepped in with open market purchases, not because of pressure on reserves, but "to contribute to the maintenance of an orderly bond market..."2

The further development of this facet of monetary policy during the war is a familiar story, and I shall not belabor it here. The rate structure from $3 / 8$ per cent on Treasury bills to $21 / 2$ per cent on long-term issues was held until 1945, at which time the shift to the longer-term issues forced the Federal Reserve to buy shortterms, which created bank reserves, which abetted the inflation we were attempting to restrain.

With the rising volume of bank loans in 1946 the shift out of governments (short and long) became even more inflationary as the resulting creation of reserves resulted in a creation of new money destined for rather immediate expenditure.

In 1947, non-bank holders also began a substantial unloading of government securities as more attractive alternative earning opportunities developed.

Periodic increases in the short-term rates and an expert use of Treasury surpluses did exert some moderate restraint on the bank credit inflation, but the modest approach (as it was called) inevitably produced comparatively modest results, because financial institutions could always bail themselves out of pressure through sales of government securities at supported prices.

\section{II}

Why was the Federal Reserve so reluctant to modify in a more substantial way its support policy during the postwar boom? If it was inflationary during an inflation, why was it not changed?

A consideration of these questions takes us into the heart of the whole concatenation of monetary problems arising out of the existence of a large public debt. There were, I think, three main

2 Twenty-sixth Annual Report of the Board of Governors of the Federal Reserve System, Covering Operations for the Year 1939, p. 9. 
reasons - all quite short and forthright. They were and are important because they are the background considerations which may well be the raw material for monetary policy again in another boom.

1. A rise in the level of rates would be objectionable because the market value of outstanding securities would fall, the Treasury might experience refunding difficulties, and it would have unfavorable repercussions on financial institutions.

2. A rise (at that time even in short-term rates) would be undesirable "because it would increase the cost to the government of carrying the public debt." 3

3. There was "even less reason to suppose that it would be of value in combatting inflationary dangers which have arisen from two primary causes, neither of which would be corrected by higher rates."4

Since these considerations are still very much a part of our current thinking, it is essential that we examine in order some of their implications.

1. That a rise in rates would induce a decline in the price of outstanding securities (government as well as others) is incontestable. The two effects are basically different sides of the same operation. Whether that rules out the desirability of a rate rise is another question. There is some reason to think, for example, that some considerable part of the unloading of longer-term government securities in the early part of 1948 might have been discouraged if the support prices had been set slightly below par instead of slightly above in late December, 1947. In that case institutions and other potential sellers would have had to face the prospect of converting a paper loss into an actual loss if they unloaded government obligations in favor of higher yielding private debentures or securities.

It is a question of judgment, of course, as to how restrictive a slightly below par price would have been at the time the decision was made in December, 1947. This much it seems reasonable to say. A slightly below-par price probably could have been found which would have imposed a penalty on sales without being so drastic a decline below par as to raise questions about public confidence in securities. And in the process, funds would not have 31945 Annual Report of the Federal Reserve System, p. 5.

4 Ibid, p. 7 . 
been made quite so readily and automatically available to private borrowers.

A par support policy cannot be justified on the grounds that the solvency of financial institutions would thereby be impaired, though that was a consideration occasionally expressed at the time (and was mentioned in the 1945 report). Most institutions would not have been required to carry their government securities at less than par, and no question of capital loss would have been raised unless they actually had sold the securities-which is precisely what it was desirable to discourage at any event. Furthermore, it has been shown that any temporary disadvantage of higher rates because of lower security prices would very quickly have been offset through higher earnings thereafter. 5

It may, in fact, be questioned just where the interests of financial institutions lie in the long run - with relatively flexible rates and security prices or with fairly rigidly supported prices and rates. The commitment to support the price of bonds at par is no part of the bond contract. The Treasury initially committed itself to pay, for example, on a $\$ 1,000$ bond $\$ 25$ per year and $\$ 1,000$ on the due date. If now the provision is added that the holder can at any time unload for face value, even long-term bonds become very close to pure cash. It would not then be surprising if some questions were forthcoming about whether $2 \frac{1}{2}$ per cent were not a rather heavy interest burden on an obligation with no credit risk and apparently also no market risk.

The commitment to bail the holder out at any time is no part of the contract, that is, at the outset. It can be argued with some force that the longer security prices are prevented from falling below par, the greater does become the moral commitment. And the more confused the public will then get about the extent to which a decline below par is in some sense a breach of promise on the part of the government - a default on its full faith and credit.

2. That a rise in interest rates would increase the interest cost of the debt to the Treasury is scarcely open to question, though the point was probably overemphasized. The rates to be pushed up first were the short-term obligations. And the subsequent "modest policy" demonstrated that comparatively moderate increases periodically made could keep the market enough off-balance to exert considerable effective pressure. Moreover, somewhat

5 Panl A. Samuelson, "The Effect of Interest Rate Increases on the Banking System," American Economio Review, (March, 1945), pp. 16-27. 
in excess of $\$ 20$ billion of government securities were held by the Federal Reserve Banks, and any added interest cost on this part of the debt could be, as it subsequently was, returnable to the Treasury. Nevertheless, the fact still remains that with a $\$ 250$ billion debt the interest cost will eventually rise at the rate of $\$ 2.5$ billion per 1 percentage point increase in the interest rate thereon.6

Now this brings us to an important aspect of this question. In our discussions of fiscal policy, a major limitation to an expansion of the public debt was considered to be the interest charge relative to national income. 7 Our postwar experience raises the question as to whether this is the burden. Nevertheless it is certainly an important one, and $I$ think we are justified in raising the question as to whether, in view of a tax and deficit conscious Congress, the limitation imposed by this burden is not already beginning to press in upon us at around 2 per cent of our gross national income. It may be that the trouble arises because Congress takes too narrow a view of this limitation. They are not sufficiently aware that economists are prepared to be sanguine about even larger relative transfer payments. (Economists qua economists, that is, are thus sanguine. The views of economists qua taxpayers, one observes, are often not so different from those of more common clay after all.) The plain fact is that the jaundiced view which Congress would take of a request for more money to pay higher interest rates on the public debt does constitute a very serious problem with a debt the present size and is already a real limitation to a rational debt management policy during a boom. In the present state of knowledge, the bacon Congressmen are elected to bring home is not more taxes to pay, more interest income to those who, it is suspected, have too much money anyhow.

This the Treasury knows. Consequently it has a perfectly understandable bias in favor of low interest rates, and the bias can be expected to be a function of the relative size of the debt. One will grow as the other grows. Each time the Treasury requires funds, it will accordingly be inclined to a rate on the low side. Furthera more, it will be inclined to short-term securities, which now carry a lower rate, which also means the Treasury is more continuously in the market on refunding operations, which makes Federal Reserve support of the market seem even more essential to the Treasury.

s The full effect would, of course, be felt only after sufficient time had elapsed so that all outstanding obligations had been refunded.

7 Evsey D. Domar, "The Burden of the Debt and the National Income," American Economic Review, (December, 1944), p. 800. 
The Federal Reserve's dilemma is then posed. They can restrict credit to restrain the boom, which will force rates higher, which means the Treasury's refunding operation fails because its issues are at unattractively low rates, which probably also means a congressional investigation, etc. Or they can assure the success of the Treasury's operations by appropriately easy money, which means easy money for all, which is inflationary during an inflation.

3. Would a rise in interest rates have stopped the inflation? Just how important, in other words, is monetary policy in determining the level of national income. This is really the basic question. The Federal Reserve's skepticism about the potential effectiveness of monetary policy during the postwar period was probably justified to a considerable extent. In that period people were wanting goods badly, and they could pay for them. This simply added up to a volume of effective demand out of any reasonable relationship to our capacity to produce, and any reasonably restrictive monetary policy probably could not have pruned it back sufficiently.

a) In part, however, this skepticism probably reflected also the increasing reservations developing prior to the war about the extent to which interest rates were after all a very important part of spending and saving decisions. They did not seem, in the short run at least, to have much effect on consumer spending out of income. Nor did it seem probable that a change of a per cent or so in interest rates would be important to a business contemplating an investment outlay. This line of analysis has tended, I think, to take too narrow a view of the phenomenon in question, and this has not served us well in the postwar period.

It is essential to remember that when we used the term interest rates, we were really using a sort of symbolic shorthand to cover the whole phenomenon of availability of funds. But then we tended to forget that the term interest rates was merely a symbol, started analyzing the symbol as the substance, and came to the not surprising conclusion that it was not a very important determinant of the level of business activity. We thereby overlooked the fact that the phenomenon of rising interest rates means a great deal more than just charging the borrowing customer a half per cent more or so on a loan. It means that loan applications get more careful scrutiny. Some get pruned down. Others are turned down altogether, which would earlier have been granted. Financial institutions on investment account begin to pursue a wait-and-see 
attitude, with the result that new issues become difficult to float on favorable terms. The increasing institutionalization of personal savings means that their availability to borrowers has become extremely sensitive to prospective changes in interest rates. Thus, savings out of income (i.e., the position of the consumption function) may be little affected by interest rate changes, but the availability of the savings to borrowers is very much affected, probably more so than in the past.

b) A large part of our difficulties in pursuing a restrictive monetary policy during the postwar boom stemmed from our having forgotten, or at least unduly underestimated, the significance of some sort of a Wicksellian concept of a normal rate of interest. Wicksell defined the normal rate of interest, you will recall, as simply "the rate of interest at which the demand for loan capital and the supply of savings agree..." 8 On the one side is the demand for loan capital on the part of those households and firms with ex ante deficits. They expect to spend beyond incomes. This total demand for loan capital represents expected deficits in the budgets of households and firms which require financing. For these units outlays are expected to exceed receipts by the extent of deficits.

These deficits require financing. In equilibrium an interest rate is arrived at which equates the extent to which the deficit spenders spend in excess of income with the extent to which the savers spend short of income. Total spending, and therefore the level of national income, is just sustained. The excess spending of the "deficit" spenders is just offset by the "not-spending" of the savers. The demand for loan capital and the supply of savings are equal, with the interest rate representing the intensity of the pressure of the one against the other. The rate of interest, to use one of Professor Schumpeter's phrases, represents the "coefficient of tension" in the system - the intensity of demand for present balances to finance deficits.9

In the postwar inflation the magnitude of these deficits was not subject to the constraint of the volume of "not-spending" by the savers. Almost everybody was trying to push spending ahead of income. This normally would have resulted in an accentuated pressure of deficits against the limited volume of ex ante savings.

8 Knut Wicksell, Lectures on Politieal Economy, Vol. II, Money (London: Routledge, English edition, 1935), p. 193.

J. A. Schumpeter, Business Cycles (New York: McGraw-Hill, 1939), p. 126. 
The "coefficient of tension" would have mounted and only the more urgent deficits would have materialized.

But deficits in the postwar period were very readily financed in all sorts of ways. Bonds could be unloaded at attractively supported prices. Or a moderately higher rate than on government securities tempted prospective lenders to dump government securities and take on non-government earning assets. The rate at which funds could be obtained was substantially lower than the normal ratedefined as the rate at which the demand for loan capital and the supply of savings are equal. In Wicksellian terms the monetary rate was below the normal rate. Ex ante deficits were in excess of savings, and on each successive "round" aggregate spending rose.

The moral of the story is: The position of the monetary rate relative to the normal rate is, after all, important. We may disagree as to whether the monetary rate's agility is very sufficient to keep it close to the normal rate, but we overlook at our peril the fact that the normal rate does exist. My own view is that the monetary rate, if within its ambit is included (as it should be) the whole concept of the terms of availability of funds, is given credit for less agility than it actually possesses.

One condition was, however, involved in this process-that the government obligations could be unloaded. This implied that there was something to unload them on, and that unhappy institution in the postwar period was the Federal Reserve. The arrears of consumer and business capital meant a high normal rate. An appropriately high monetary rate meant low bond prices. Sustained bond prices meant a low monetary rate, spending continuously accelerating, and more price inflation. There was the dilemma of the postwar boom.

c) There are two implications of this which are worth mentioning here. A wartime rate structure should be set with particular regard to whether it will be tenable in the postwar period. Wartime stability of rates, essential as that may be, is a secondary issue. With the elaborate direct ec.ntmle and a strongly organized central or reserve banking system, most any reasonable rate structure can be maintained during the war. The real question is whether the terms of obligations issued during the war will be reasonably articulated with the postwar economic facts of lifeto be specific, the Wicksellian normal rate. It may, in other words, be desirable to finance the war at rates higher than necessary incident to war financing if the existence of the debt is not to serve as 
a major instrument of inflation in the postwar period. The rate structure of World War II was on the contrary more nearly retrospective-geared to the depression developments of the prewar decade. Rates were thus about two notches below an appropriate level in the postwar period.

But the main significance of this side-trip into theory is that interest rates on government obligations, long-term as well as short-term, may be persistently below the normal rate. If so, very important questions are posed. We may not know the answers but there is little disposition to doubt that the questions exist, and that they are very real questions. Will the demands of our economy on consumer account, investment account, foreign account, and government account add up to a chronic tendency for ex ante deficits to be in excess of savings? If so, yield rates on government obligations must rise, or the alternative will be abetting upward pressure on prices. But more of this in a moment.

\section{III}

1. What we have witnessed here, of course, is the progressive sterilization of monetary policy by fiscal and debt management policy. That is, I think, increasingly generally recognized. ${ }^{10}$ What may not have been so obvious is that this inability to pursue a restrictive monetary policy during a boom may also be going a long way toward neutralizing an effectively restrictive fiscal policy. The restrictive effect of a governmental cash surplus, for example, may largely be lost if households and firms can bail themselves out of this limitation by borrowing or by ready sales of government securities. We get, in other words, a chain reaction. Monetary policy is immobilized because of the apparent requirements of fiscal and debt management policy. This immobilization in turn tends to neutralize the effectiveness of fiscal policy.

The substantial corporation income tax in and of itself, for example, undoubtedly constituted some restriction on these firms' postwar expansion plans. On the other hand the effect was materially blunted because corporations had recourse to a liquidation of government securities from 1945 to 1948 of $\$ 7.2$ billions plus substantial bank borrowing to offset this constraint, and it was unquestionably a substantial offset. 11

10 For some prophetic words on this point see D. H. Robertson, Essays in Monetary Theory (London: Staples, 1946), p. 131.

11 "Working Capital of U. S. Corporations," June 30, 1949, Securities and Exchange Commission Release No. 892. 
Now this inability of monetary policy to come to grips with a boom has been a rather bizarre finale to the story. The shift in emphasis to fiscal policy in the prewar decade was thought to be precisely because it was not a boom, but a depression with which we then had to deal. Monetary policy was considered to be effective certainly and appropriate probably (there was less agreement on that point) to check a boom. "The monetary weapons can, indeed, be applied effectively to check an expansion," stated Professor Hansen, probably summarizing prevailing opinion on the subject.12

What started out as a procedure to gain the initiative in a depression seems to have resulted in our losing the initiative in the boom also.

2. It may be argued that this less than delightful turn of events policy-wise stems not from the operation of fiscal policy, but simply from the war legacy of a huge public debt that had to be managed. There is, of course, much force to this argument. The debt certainly grew at a rate which was never contemplated in the more responsible deficit-spending discussions about the affirmative use of fiscal policy to combat depressions. On the other hand the point should not be overemphasized.

In our discussions of fiscal policy in the prewar decade we were quite evidently prepared to think that a necessarily vigorous exercise of fiscal policy might well lead to a considerably larger public debt. With that in mind a great deal of our thinking regarding fiscal policy had to do with precisely this question of the burden of a domestically held debt. Particularly was this possibility of a substantial rise in the public debt an explicit part of our thinking in connection with the mature economy thesis. It is difficult to believe, therefore, that the war debt poses any fundamentally new problems which we might otherwise never have had to face. There is, on the contrary, a great deal of reason to think they would have faced us in any event anyhow.

3. A further question may be raised as to whether a great deal of this is not water over the dam since the announced change of policy in June of this year. At that time, as mentioned earlier, the Federal Reserve took advantage of the fact that market strength had lifted bond prices off the support levels to announce that:

12 Alvin H. Hansen, Fiscal Policy and Business Cycles (New York: W. W. Norton \& Company, Inc., 1941), p. 71. 
"The Federal Open Market Committee, after consultation with the Treasury, announced today that with a view to increasing the supply of funds available in the market to meet the needs of commerce, business, and agriculture it will be the policy of the Committee to direct purchases, sales, and exchanges of Government securities by the Federal Reserve Banks with primary regard to the general business and credit situation. The policy of maintaining orderly conditions in the Government security market, and the confidence of investors in Government bonds, will be continued. Under present conditions the maintenance of a relatively fixed pattern of rates has the undesirable effect of absorbing reserves from the market at a time when the availability of credit should be increased."13

Does this not mean that monetary policy's indenture to fiscal and debt management policy is concluded, and that monetary policy will again pursue its more historic function of having to do with general economic stability? Perhaps. It is to be hoped that this constitutes a substantial step in that direction. There is, however, reason for being less than certain about how fundamental the change really may turn out to be.

The "policy of maintaining orderly conditions in the Government security market" and encouraging "confidence of investors in Government bonds," which is to be continued, was the point d'appui for the monetary problems which bedeviled us during the postwar boom. The question still remains, therefore, as to how differently we might wind up again if we were to experience another substantial boom, since we would be starting from about the same point.

The real question is whether the June announcement constituted a recognition of changed conditions or whether it represented a fundamental change of policy. The final sentence of the release indicates that the former was presumably a substantial consideration. With the inventory recession, private demand for credit began to weaken. Funds seeking investment were turning more toward government securities, and the resulting market strength carried their prices off the pegs. The pegs consequently could rather readily be removed without our having to face the implications of a freer market for government securities with higher rates. In fact, prior to June this year the Federal Reserve, in

13 "Press Release of June 28, 1949," Federal Reserve Bulletin, (July, 1949), p. 776 (italies mine). 
endeavoring to support the stipulated price levels, found themselves selling securities in response to market demand - a policy which had the effect of holding interest rates up during a recession.

The real test of the extent to which there has been a substantive change of policy will come with the next business upsurge. Private demand for credit will then be strong, and funds will start shifting out of governments and into higher yielding non-government earning assets. Prices of government securities can then be expected to sag, and the conflict between debt management policy and "primary regard to the general business and credit situation" will then be posed in a way which it is not posed in a recession. Will "orderly conditions" be interpreted then as preventing only a cumulative speculative collapse of government security prices, although allowing them to fall to some sort of equilibrium level, even if that should be below par? The answer is by no means a selfevident yes.

In his remarkably candid December 1,1949 , letter to Senator Douglas, Mr. Eccles suggests that he, at least, also does not feel that the Federal Reserve is as yet in a position to pursue a sufficiently restrictive money policy in the event of inflationary pressures. In his letter, written early this month, he cogently argues:

"Under these conditions it can hardly be said that the Federal Reserve System retains any effective influence in its own right over the supply of money in the country or over the availability and cost of credit, although these are the major duties for which the System has statutory responsibility. Nor can it be said that the discount rate and open market operations of the System are determined by Federal Reserve authorities, except in form. They are predetermined by debt-management decisions made by the Treasury. This will be true as long as the System is not in a position to pursue an independent policy, but must support in the market any program of financing adopted by the Treasury even though the program may be inconsistent with the monetary and credit policies the System considers appropriate in the public interest."14

14 Statement of Marriner $S$. Eccles before the Subcommittee on Monetary, Credit, and Fiscal Policies of the Joint Committes on the Economic Report, November 22, 1949, and Supplementary Letter to Senator Douglas of December 1, 1949 (Washington: Federal Reserve Board of Governors), p. 7. 
4. This emergent dominance of debt management policy is sometimes described as a Treasury-Federal Reserve or Federal ReserveLending Agencies conflict. There is no question but that these seem to be the principals. It seems to me, however, that to characterize it in this manner is to describe the symptom rather than the substance. The problem is more basic. It represents a lack of articulation in our total economic and social policy measures and objectives. By and large we liked almost everything about a period of rising prices, except rising prices. The feeling of excess demand for practically everything was particularly comfortable in view of our legacy of depression-mindedness.

The postwar boom illustrates this well. Were some people's housing needs not being met? Was it because people could not pay the prices? Very simple. Let them borrow more -100 per cent, if necessary. Did that make the monthly terms too high? Equally simple. Extend the period; lower the rates. And it was done.

Were taxes a constraint on spending? Then Congress must lower them. And it did.

Was the burden of paying interest on the debt apt to be onerous? The solution? Well, the interest on a debt twice as big is the same if interest rates are half as high. Iet the Treasury keep that in mind. And it did.

Is a bond more valuable at par than below par? Then let the Federal Reserve know it is expected to keep them at par. And i仑 did.

This could be expected to add up to an economic situation that did not particularly please anyone. And it did.

In short, until we have made more clear, and perhaps seen more clearly ourselves, cause-and-effect interrelationships, the ramifications of some of these policies, we can certainly expect a continuation of the demand to have our cake and eat it too.

We shall again in a boom insist on low prices and then keep them higher through low interest rates. We shall continue to demand lower construction costs and then force them up with more generous mortgages. And the apparent altercations between the Federal Reserve and the Treasury or the Federal Reserve and the various other lending agencies will be little more than a reflection of our own inability to arrive at a seasoned, mature, responsible, and reasonably consistent economic policy. 
Something might, I think, be accomplished by the formation of a National Monetary Council, as recommended by the Hoover Commission, composed of representatives of the Federal Reserve, the Treasury, and other regulatory and lending agencies. In this way a formal, organized procedure for airing all points of view (particularly the Federal Reserve's) would be provided, and the probability of agencies being oblivious to contradictory policies might be minimized. This would be all to the good, and might result in some greater consistency of policy.15

We should not, however, expect too much from it. If these intraagency conflicts are largely reflections of internal contradictions within our total social and economic policy, they will not be liquidated by appointing the contending principals to the same committee.

In the final analysis our success in dealing with this problem is going to depend largely on how clearly Congress and public opinion see the implications of available alternatives. So far as debt management and monetary policy are concerned, there are three.

a) We can continue as at present with the Treasury largely the architect of monetary policy through decisions on the terms and rates of public debt issues, and with the Federal Reserve taking the necessary action to implement these decisions. This means the continuation of low interest rates, not only for the public debt, but generally. More importantly, it means only a negligible monetary defense against upward price pressures, through the maintenance of a monetary rate below the normal rate.

b) If we insist that something be done monetary-wise in case of inflationary developments, but are unwilling to permit higher rates or adequate flexibility in government security prices (which may mean below-par prices) we must then be prepared to accept a possibly increasingly complex method of forcing holders of bonds to hold their bonds.18 The special reserve proposal outlined by the Federal Reserve in 1947 points one way-the proposal that banks be forced to hold a designated proportion of their assets in certain government securities. It will not be enough, however, to apply it merely to banks. Other holders must be included also. It is well not to forget for example, that holdings of government securities by insurance companies declined $\$ 3.8$ billions during 1947 and 1948. Theoretically all holders, including individuals, should under

15 G. L. Bach, "The Federal Reserve and Monetary Policy Formation," American Economic Review, (December, 1949), p. 1189. 
these circumstances be required to hold obligations up to some designated amount.

The issue here is simple. If the terms of the government obligations are not sufficiently attractive to induce their being held voluntarily, people must be required to hold them involuntarily.

c) We can reactivate the Federal Reserve mandate to determine monetary and credit policy with respect to the general economic situation. This means, among other things, we must be prepared to see some more flexibility in bond prices, in order that the relstionship between the monetary rate (availability of funds) and the normal rate will be more consistent with broad economic policies.

The most difficult question, of course, is whether the degree of flexibility required to exercise monetary restraint (particularly if below-par prices were required) would precipitate an unacceptably disorganized market. It may be that more of the public debt will need to be refunded into non-marketable securities with redemption before maturity subject to a pensity discount, or perhaps consols the Federal Reserve will explicitly make no attempt to support.

The degree of flexibility contemplated even so would not presumably be very vast. The institutionalization of savings, together with the size of the public debt "have made the money market much more sensitive to relatively modest action than was formerly the case."17 This does not, in short, mean the Federal Reserve should during inflation kick the props out and "let 'er rip." It is to be hoped that discouraging disorderly and disorganized developments in the bond market does not need to mean fairly rigid support-that there is no compromise between a chaotic and a frozen market. It must, however, be admitted that in the practical operation of monetary policy this distinction is both extremely necessary and extremely difficult to make.

This does not mean that monetary policy is expected by itself to solve the riddle of economic stability. It does mean that it be free to operate in the right direction, rather than in the direction of being unable to restrain the boom and at the same time neutral-

16 Woodlief Thomes and Ralph A. Young, Problems of Postwar Monetary Policy, "Postwar Economic Studies," (Board of Governors of the Federal Reserve System, November, 1947); "Proposal for Special Reserve Requirement against the Demand and Time Deposits of Banks," Federal Reserve Bulletin, (January, 1948), pp. 14-23. 
izing a restrictive fiscal policy, as is quite possible under present conditions.

The third alternative does mean, in short, responsibly engineering that degree of flexibility in yield rates which will in fact demonstrate that the public debt is not a slightly sophisticated greenbackism, and will encourage holders of government obligations to understand that their bonds are not to be considered as practically cash.

\section{IV}

If we can regain somewhat more initiative with respect to monetary policy, we shall not then need to rely quite so exclusively on fiscal policy. This is all to the good-not because fiscal policy is bad, but because it is always better to work from more than one angle if possible. Moreover, it may be essential to gain somewhat more initiative with monetary policy if fiscal policy, particularly in a boom, is not also to be neutralized.

By fiscal policy I mean simply the impact on the volume of economic activity of the governmental receipts-spending process. There would be general agreement, I think, that this impact is apt to be quite substantial for some time to come. To this even those who are made somewhat uncomfortable by the prospect would probably agree. It seems to follow that if the effect is going to be quite substantial in any case, it should, where possible, work in the right direction.

As the economists, meeting under the auspices of the National Planning Association, have very cogently pointed out: "If we do not adopt such a policy deliberately we are likely to be forced into an imperfect version of it through the pressure of events." 18 This means that when private demand and spending is weak, the governmental receipts-spending process should help things out. This it can do either by dipping less taxes out of the income stream, and thus encouraging private spending, or by stepping up its own spending, and thus supplementing private demand (spending). During a boom, the process should work the other way around.

The affirmative theory of the thing has been worked out in considerable detail, and is almost a part of the lore of economic policy.

17 Allan Sproul, "Monetary Management and Credit Control," Monthly Review, Supplement, Federal Reserve Bank of New Xork, January, 1947), p. 6.

18 Hearing before the Joint Committee on the Economic Report, September 23,1949 , p. 7 . 
I do not propose to try to add anything here along that line. I do not believe our difficulties in the more expert operation of compensatory fiscal policy arise out of any serious lack in the development of the theoretical principles. On the other hand, even those who have been very sympathetic with what it might contribute to economic stability, of which I am one, have become increasingly dișturbed by certain other questions. My own view is that satisfactory answers to these questions must be found before we can proceed much farther in the use of compensatory fiscal policy. It may be useful to pose a few of them here.

1. Can we find ways to minimize some very real limitations to a variable spending policy?

a) Just as emphasis early was primarily, though by no means entirely, on public spending, so also some of our early uneasiness has had to do with how readily in practice the volume of public spending could be altered in a contracyclical manner. So far as public works spending is concerned, the construction industry has long been recognized as too narrow a funnel to pour in an amount of spending which might be necessary in a substantial general business dectine. What might rather be aimed at would be a sufficiently contracyclical pattern of public works spending to encourage greater stability in the construction industry. Since it has traditionally been one of the more volatile sectors of the economy, this would be no mean contribution to stability generally.

b) One of the more serious questions about a compensatory spending program is how to make sure it increases employment and production rather than prices and costs. We found early in the defense and war program that a cost-price inflation began to develop long before we had reached a reasonable maximum of production and employment. To be specific, the wholesale price index during 1941 advanced 13 percentage points (16 per cent) even though unemployment averaged 5.6 million during the year. Our experience was somewhat similar during the 1936-37 boomlet, though the picture was complicated by the wage increases incident to labor's organizing some of the basic industries.

Perhaps some part of the trouble then was that we had operated too long at low-production levels. Inadequate capacity in some industries bottlenecked the general expansion and forced prices up before full production could be achieved. If so, the problem should be less serious in the period ahead since the various segments of the economy are better geared to high-production levels. 
My own view is, however, that this will be more than offset by the greater power of organized labor to force up wage rates in excess of rising rates of productivity-thus leaving the problem of a cost-price inflation still very much with us.

c) But the most difficult problem incident to a contracyclical spending program has to do with the hard question of timing. It has generally been argued that these measures should be launched fairly shortly after the beginning of the decline. This seems to be a very reasonable proposition, but it is exceedingly difficult to put into practice. It is simply not easy to know very promptly just where we are in the cycle. A review of some of our past discretionary policy actions, most of which have to do with other things than the timing of expenditures, is very illuminating on this point.

There is, of course, the President's Economic Report to Congress transmitted in January, 1949. The report was largely oriented about "policies to Combat Inflation. . . ."19 From these policies we were saved by what has often been considered a major obstacle to a rational contracyclical program - the considerable time it takes Congress to act. By January, it is now evident, we were well along on the 1949 inventory recession, the wholesale price index had been declining for five successive months (the peak was in August, 1948), and unemployment had been rising after October.

The Federal Reserve, rightly credited with somewhat greater agility, has had a somewhat similar experience. Their request of Congress for reimposition of Regulation W (consumer credit control) and additional powers over member bank reserves was made in August, 1948, the final month of the price rise. Congress acted with unusual speed, and the anti-inflation powers were inposed beginning in September, after the price level had begun its decline. It must, of course, be said that the Federal Reserve did reverse itself with reasonably commendable promptness in 1949.

Though it is not usually rated highly by economists, there is considerable reason to think that the best-timed performance in discretionary, compensatory fiscal policy was the May, 1948, tax reduction-nonetheless expertly timed because its proponents were not known to be devoted to the New Economics. It came just four months before the beginning of the price decline, and the refunds

19 The Economic Report of the President transmitted to Congress, January, 1949 , p. 11. 
were paid out early in 1949 after the recession was getting underway.

I do not cite these in an sense as criticisms of institutions or individuals. In each case there was recourse to eminently qualified and able experts. Rather these experiences serve to show how extremely difficult it is to know where you are. But until we can do better at this, we cannot expect to do very well in prompt and effective timing of discretionary policy actions.

2. These considerations have turned our attention increasingly to the concept of built-in stability. The Committee for Economic Development, among others, has done a great deal to educate us on this point. The idea is basically quite forthright.20 "Set tax rates to balance the budget and provide a surpius for debt retirement at an agreed high level of employment and national income. Having set these rates, leave them alone unless there is some major change in national policy or condition of national life."21

a) This has two advantages. It largely avoids the difficult timing problem. As national income declines, a cash deficit automatically develops because, with our progressive tax structure, tax receipts decline rapidly and certain outlays (e. g., unemployment compensation) automatically rise. Conversely, tax receipts rise relatively to expenditures on the upswing and the surplus grows as the need for it grows. The economic process is subject to a sort of governor that tends to control the speed of operation.

It relies more heavily on sustaining private spending rather than compensating for its deficiency through added governmental or collective spending.

b) With the rapid development of social insurance programs and our currently substantially progressive tax structure, we have already accomplished a great deal along this line. A correlation of disposable personal income with gross national product shows that for the period of 1929-37 (covering the decline and recovery, but before Social Security had become important), the regression equation is $Y_{d}=2.805+.769 \mathrm{GNP}$. For $1939-41$, on the basis of seasonally adjusted quarterly data, the equation is $Y_{d}=12.392+.629$ GNP; and for the five quarters, 1948 third quarter to 1949 third quarter, $Y_{d}=118.90+2868 \mathrm{GNP}$. These are subject to numerous

20 Monetary and Fiscal Policy for Greater Economic Stability, Committee for Economic Development, December, 1948, p. 38.

21 "Taxes and the Budget," Committee for Economic Development, 1947. Quoted in the 1948 report cited above. 
limitations. A considerable dispersion is probably inevitable. The number of observations is small. The postwar period has been subject to special influences. It is not always easy to separate periods in order to distinguish the effects of a changed tax structure from a change in the tax structure.

Even so, the evidence seems to me to be reasonably clear that disposable personal income has become less and less sensitive to changes in the level of general business activity. Each successive period's coefficient of regression is lower than the preceding one. For 1929-37 a change of one dollar in gross national product was associated with a change of 77 cents in disposable personal income; in 1939-41 it was one dollar to 63 cents; and during the five most recent quarters for which data are available, it has been one dollar to 23 cents. (Perhaps here is a substantial part of the reason the 1949 recession was so mild.)

c) There are three major limitations to which this governorlike arrangement is subject and which deserve mention here.

(1) A recession may be sharp enough that more powerful action is required. The Committee for Economic Development recognized that in these circumstances "a temporary reduction of tax rates may be desirable to stimulate private expenditures." 22

(2) Taking less of incomes in taxes undoubtedly encourages greater private spending, but it does not guarantee it. Even if the consumption function does not decline, larger deficits may be required than with public spending since a part of each added income dollar is usually saved (the marginal propensity to save is greater than zero).

(3) There is a basic conflict between the concept of built-in stability and economic progress if the former is pushed too far. This governor mechanism works most effectively, of course, when the tax take is extremely sensitive to changes in the level of national income. This means that a correspondingly substantial proportion of each added national income dollar must go in taxes. This also means that the net difference between mediocrity and doing things better is diminished in a parallel manner. There is unquestionably considerable room for disagreement as to just how far we can go along this line before economic progress is jeopardized; there is less room for argument that the problem exists.

3. Has compensatory fiscal policy tended to divert our attention from very real economic maladjustments in the economy? I think 22 Monetary and Fiscal Policy for Greater Economic Stability, p. 33. 
it has had that result. I do not mean by this to suggest that the business cycle is primarily a matter of economic disease rather than "real" factors such as fluctuations in investment incident to innovations. Nevertheless in any particular situation maladjustments may be a large part of the problem. Let me cite a few illustrations of what I mean.

a) The Great Depression was a great depression largely because of the 1931 to 1933 phase. This, in retrospect, presents itself as largely a sort of pathological monetary panic. In less than two years following mid-1931 we lost one-third $(7,000)$ of our banks and through credit contraction extinguished $\$ 15$ billion of our money supply! These are little short of fantastic figures. It would require no concept of a chronically weak marginal efficiency of capital to explain why we went so low-or why for the better part of a decade thereafter we seemed to be plagued by a condition of almost absolute liquidity preference. The Great Depression was a great depression largely because of a specific maladjustmentthe vulnerability of our banking system.

b) One of the particularly disappointing features of the recovery after 1933 was the continued low level of private construction. Private construction activity made no significant recovery until 1936 , in which year it was 33 per cent of 1929 . (The 1936 gross national product was 79 .per cent.) It may have been that we were in the wrong phase of the eighteen-year construction cycle; there is some evidence that we were. Nevertheless, in the period from July, 1936 to September, 1937, a period of general unemployment, particularly low construction activity, and during which time we were trying to encourage recovery through public works spending, construction costs as indicated by the E.N.R. construction cost index increased 22 per cent, and Boeckh's indexes of residential construction costs for the four listed cities registered increases up to 19 per cent.

c) The same questions can be raised about the public housing assistance currently. Instead of floating the industry off the rocks with public assistance, it might have been the better part of wise economic policy first to see why the industry could not operate more effectively in a period of substantial latent demand and easy money. Is there labor-management collusion? What about local monopolies of materials? Building codes? We would probably have wanted a substantial public housing program in any case. If so, it could have been just that much more effective if the 
industry itself were placed in a position to give more for the money.

4. Have we given adequate attention to the significance of the size of the budget, even if balanced?

The fact that government outlays have increased, or are large, is not necessarily a cause for alarm. In a very real sense it is a measure of our development above the jungle economy. We can now afford certain social programs, always desirable but heretofore out of reach. Moreover, many of these outlays open up or facilitate private economic development. The automobile industry could not have attained its present proportions had we been unwilling to do some of our spending collectively to build a road system.

A large relative volume of governmental outlays does, however, pose some problems, and economic statesmanship requires that we be willing to face them.

a) Beyond a certain point, to the extent that we spend our incomes collectively through the agency of government the less we shall have to spend individually. If we have more battleships, we may have fewer cars. If we have more collection of statistics, we may have less to collect statistics about.

b) As the relative size of governmental outlays expands, there results greater upward pressure on the demand side even if the budget is balanced. For any individual what he gets through government is not subject to the budgetary or income restraint that the more he gets the bigger the bill. The rules of the game encourage pressing for more. What is true for one is true for all. The price tags tend to be removed, and payment becomes a separate consideration.

The issue is particularly clearcut if through progressive or corporate income taxes we can apparently shift the burden to others-thereby perhaps also helping those who presumably have too much anyway to squeeze a bit more readily through the needle's eye. It is imputing no bad motives to people to say that with this payment constraint removed or diminished, total demand tends to rise. The advantage of each separate governmental outlay tends to be concentrated on a particular group, but the cost is diffused over the whole society. Each separate project thus seems to be a "good deal." The fact that it adds up to a volume of total outlays about which nobody is very happy is not too difficult to under- 
stand. The result is an upward bias on demand that becomes progressively more important as collective consumption and income transfers (governmental outlays) represent a larger proportion of the economy.

c) How serious this is depends on the collateral effect a large governmental budget (even if balanced) has on our capacity for economic growth and progress. We can easily take this matter of rising productivity too casually-as something that, like old age and maturity, more or less occurs with the passing of the years. This is not necessarily the case. Productivity has increased because ways have been found to make an hour of human endeavor turn out progressively more and more of the good things of life without harder work.

While governmental outlays at 23 per cent of our gross national income are probably not at the peril point, they are large enough to make a consideration of these issues in order. Particularly is this so with the current tendency to extrapolate future demands on the economy on the assumption that our 2 to 3 per cent per year rise in productivity will continue.

Beyond some point a large budget will begin to inhibit this process in two distinct ways.

(1) One source of rising productivity is the myriad of ways, little and big, that are constantly being discovered to cut corners on costs and improve earnings. And their aggregate effect is the sccially very desirable result of making productive resources go further. As taxes rise relative to incomes the net difference between the rewards of those who watch costs and those who do not is reduced. And one of the results of this is to weaken one of the economic pressures toward increasing productivity, toward more effective use of resources.

(2) Moreover the net advantage to the firm which reduces costs or introduces a new product through an investment program is also correspondingly reduced relative to the firm which does not so exert itself. Yet capital formation has been a second major source of our rising productivity. To the extent that firms must rely on retained earnings to finance capital outlays, this consideration becomes particularly important. Then the inducement and the capacity to invest are both inhibited as taxes bite more and more deeply into corporate income. Whatever the merits otherwise of these taxes, one result is apt to be a corresponding stifling of investment and a reduced rate of economic progress. 
These tendencies are particularly pronounced with the substantially progressive character of our tax structure,- -which paradoxically is one of the reasons we can rely heavily on built-in stabilizers. There are certainly sound, impressive reasons of social justice for a considerable progressivity in our tax structure. This does, however, have the unfortunate effect of coming down particularly hard on activities which add to income. Yet those who are not content to let well enough alone are those whose innovations and activities make a particular contribution to economic progress. This does not seem to be the proper avenue to rising productivity. We cannot, in short, dodge this question: How far can we afford to go in championing those content with things as they are and penalizing those who try for something better?

We shall, in shcrt, need to take care that the very thing we count on to enable a continued expansion of social programs does not become their victim-rising productivity.

\section{$\mathrm{V}$}

At the present stage of monetary and fiscal policy the major questions with which we must come to grips, it seems to me, are therefore these:

1. How far are we prepared to go toward a reorientation of monetary policy away from debt management considerations and toward general economic stability? Can adequate procedures be devised to facilitate this reorientation?

2. Is there a clear understanding of the implications of the alternatives?

3. Do we see that the cost of excessively rigid yield rates and prices of government securities may be devices to force holders of bonds to hold their bonds, if monetary policy is not to be both ineffectual itself to restrain a boom and a substantial drag also on an effective fiscal policy?

4. Can we avoid or minimize certain very real current limitations to the greater use of the governmental receipts-expenditure process in stabilizing business activity-its tendency to raise prices and costs before an optimum level of production and employment is attained; its tendency to divert attention away from specific maladjustments; the difficulty of timing?

5. Do we need to give more attention to the effect of these and related policies on our rate of economic expansion and progress? 
This last question is, I think, particularly important. One sometimes has the uncomfortable feeling that we are devoting a considerable proportion of our time to St. Vitus' dance, so to speak, when an emerging problem of at least equal importance may be how to avoid economic arthritis. 